IRA-International Journal of Management \& Social Sciences

ISSN 2455-2267; Vol.13, Issue 03 (December, 2018)

Pg. no. 95-106.

Institute of Research Advances

http://research-advances.org/index.php/RAJMSS

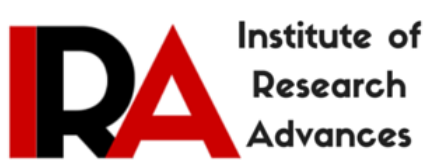

\title{
Doubling the Agricultural Income by 2022 in India: Issues and Challenges - Evidence From Andhra Pradesh
}

\author{
Dr. Srinivasa Rao Pasala \\ Assistant Professor, GVP College for Degree and P.G. Courses (A), Affiliation to Andhra \\ University, Visakhapatnam, Andhra Pradesh, India. Pin Code: 530017.
}

Type of Review: Peer Reviewed.

DOl: http://dx.doi.org/10.21013/jmss.v13.n3.p4

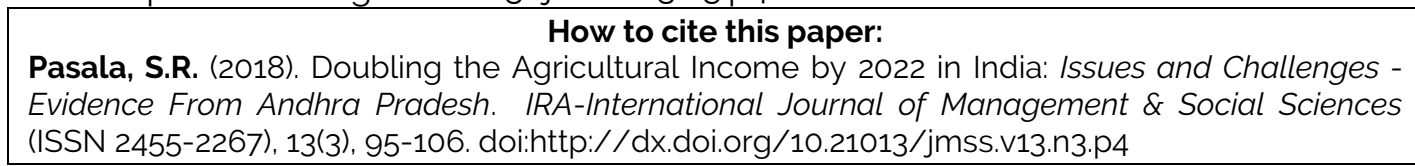

(C) Institute of Research Advances.

\section{(cc) BY-NC}

This work is licensed under a Creative Commons Attribution-Non Commercial 4.0 International License subject to a proper citation to the publication source of the work.

Disclaimer: The scholarly papers as reviewed and published by the Institute of Research Advances (IRA) are the views and opinions of their respective authors and are not the views or opinions of the IRA. The IRA disclaims of any harm or loss caused due to the published content to any party.

Institute of Research Advances is an institutional publisher member of Publishers International Linking Association Inc. (PILA-CrossRef), USA. The institute is an institutional signatory to the Budapest Open Access Initiative, Hungary advocating the open access of scientific and scholarly knowledge. The Institute is a registered content provider under Open Access Initiative Protocol for Metadata Harvesting (OAI-PMH).

The journal is indexed \& included in WorldCat Discovery Service (USA), CrossRef Metadata Search (USA), WorldCat (USA), OCLC (USA), Open J-Gate (India), EZB (Germany) Scilit (Switzerland), Airiti (China), Bielefeld Academic Search Engine (BASE) of Bielefeld University, Germany, PKP Index of Simon Fraser University, Canada. 


\begin{abstract}
The mechanism of reforms is not given enough government funding and financial assistance to the agriculture sector. This impacted the conditions of cultivation, particularly in rural living conditions. The impact of free trade brought unstable prices, difficulties in agriculture export and import and which is affected farmer's welfare, livelihood, and other employment alternatives. The most adverse effect that has become a curse to farmers is the multiple of low price and instability in the output of cash crops. Andhra Pradesh mostly depends on rainfall agriculture. Monsoon and seasonal conditions play a crucial role in Andhra Pradesh agriculture. The proportion of area under agriculture is 37.30 percent (including fish ponds). The gross irrigated area (35.81 lakh hectares) is 48.29 percent of gross area sown (74.18 lakh hectare.) in the state. The ratio of gross irrigated area to net irrigated area is 1.32 in 2016-17, where it was 1.29 in 2015-16. (Agricultural Statistics at a Glance 2016-17). An attempt is made to study in depth the evolution of cost conditions in the rainfed and irrigated land agricultural practices, regarding the sustainability of livelihood practices. Both quantitative and qualitative methods of research were applied in the study through a collection of data by household survey and in-depth interviews, site visits, and field observations. For an understanding of costs and returns, calculate Cost A, Cost B and Cost C and Gross, Farm Business, Family Labour, Net, Farm Investment Incomes. The policymakers should focus on strict implement National Commission on farmer's recommendations of increasing MSP should be at least 50 percent more than the weighted average cost of production, introduce availability of the leased technology (i.e. crop sowing and cutting machines etc.) to marginal and small farmers, reduce the inequalities between villages and towns and promote Zero Budget Natural Farming across the country.
\end{abstract}

Keywords: Cost A, Cost B, Cost C, MSP, Gross Income, Farm Investment Income, and ZBNF.

\title{
Introduction
}

Agriculture is the most imperative sector of Indian Economy. It contributes 14 percent of share to the total GVA and 10 percent of share to the total Indian Exports. Further, approximately half of the Indian rural population is still depending upon agriculture as a primary occupation. Since the beginning of the reforms have had either direct or indirect effects on farmer's welfare that have been generally in adverse. In India, economic reforms did not provide any special packages for agriculture. Rather, the opinion was that freeing agricultural markets and liberalizing international trade in agricultural commodities would provide price incentives. The underlying assumption was that such an incentive would lead to an increase in investment and output in the agriculture sector. While liberalization of trade would change inert-sectarian agreement would favour to the agriculture. But unfortunately, that remained as a dream.

The mechanism of reforms was not given an adequate amount of government funding and financial assistance to the agriculture sector. This impacted the conditions of cultivation, particularly in rural living conditions. The impact of free trade brought unstable prices, difficulties in exports and imports of agricultural products and which is affected farmer's welfare, livelihood, and other employment alternatives. The most adverse effect that has become a curse to farmers is the multiple of low price and instability in the output of cash crops.

\section{A Brief Note on Andhra Pradesh Agriculture}

Agriculture plays an imperative role in Andhra Pradesh State economy. The contribution of agriculture and allied sectors to the state gross value added for the year 2016-17 is 24.46 percent (advance estimates) on the basis of current prices. However, 62.17 percent of the working population is still depending on the primary sector. Agriculture in Andhra Pradesh mostly depends on rainfall. Monsoon and seasonal conditions play a vital role in Andhra Pradesh agriculture. The proportion of area under agriculture is 37.30 percent (Including fish ponds). The gross irrigated area (35.81 lakh hectare) is 48.29 percent of gross area sown (74.18 lakh hectare.) in the state. The ratio of gross irrigated area to net irrigated area is 1.32 in 2016-17, where it was 1.29 in 2015-16. (Agricultural Statistics at a Glance 2016-17). Government of Andhra Pradesh implement various agriculture welfare schemes under Centre assistance such as Village Insurance Scheme, Pradhan Mantri Fasal Bima Yojana Scheme, etc., With the objectives of to cover loss due to natural calamities, to motivate farmers to continue farming, to make the farmers adopt the modern and innovative technology and to ensure flow of credit to the farmers. 


\section{Need for the Study}

The agriculture depression that has devastated India's rural economy during the post-reform era has grown on a three-pronged set of symptoms: rising input costs, deteriorate produce price awareness and the instability of farmers to abandon cultivation without alternative livelihood sources. Despite governmental efforts, huge reimbursement programmes, the farmer's suicides remains alarming high in many states in India. Most of the farmers lost their lives due to loss of cultivation. This situation is not except for Andhra Pradesh. In this context, it is only the provision that agriculture comes under either low cost of cultivation and high income of cultivation. The later one is not on the hands of farmers. The low cost of cultivation practiced through the zero budgeting nature farming or organic cultivation or any other. Therefore there is a need to examine which factors are more influence on increase the cost of cultivation. This article is addressed to the current scenarios of costs and returns of cultivation in the study area.

\section{Objectives of the Study}

1. To analyze the cost and returns of cultivation in the study area.

2. To suggest appropriate policies for improving returns and reducing the cost of cultivation.

\section{Related Review of Literature}

The study costs and returns of Banana cultivation carried out by Kathirvel, N. (2013). This study mainly focused on fixed and variable cost on banana production and also finds the returns to scales of farmers. Primary data was collected from 500 respondents in Karur district in turn to analyze the technological efficiency of the farmers. CobbDouglas production function was employed to find out input and output relationship. It was found that except the imputed value of family labour, other things like cost of production, overall returns etc., are not favourable to the small farmers.

The analysis of the paper stated by Narayanamoorthy, A. (2013), farmers are suffered substantial losses by cultivating different crops. When the profits were earned by the farmers, it was found in majority of cases to be less than 30 percent over the cost of cultivation. Except in wheat and gram, the returns over the cost of cultivation had also worsened in all other crops especially during post-1990s. This study found that the quantum of loss incurred by the farmers in crops like cotton, groundnut, and sugarcane was also large in recent years as compared to the pre1990s situation. The study suggested that focus on the non-price incentives to increase the productivity of crops and also reduce the cost of cultivation, increase the public investment in agriculture, improve the credit through Public Sector Banks and also focus on irrigation facilities.

Rawal, V. (2013) uses data from the Project on Project on Agrarian Relations in India of the Foundation for Agrarian Studies to examine various issues in respect of incomes from crop production. The paper uses socioeconomic categories based on the value of owned means of production, level and sources of household income, and pattern of labour deployment to measure the scale of production. The paper primarily uses estimates of income over cost A2, which is a measure of paid out the cost, to study levels and variations in farm incomes. In 2005-06 prices, these ranged from Rs. 918 per acre in Bukkacherla (Andhra Pradesh) to Rs 7521 per acre in Nimshirgaon (Maharashtra). It also stated that a substantial proportion of households in most villages had incurred a loss in crop production. The proportion was highest (42 percent) in Rewasi, a village in Rajasthan, which had large scale crop failures in the kharif season in 2009-10 on account of low rainfall. In the study area, there was a proportional relationship between the scale of production. In most crops, hired labour, draught power, fertilisers, and irrigation were major items of costs. In case of the planted crop of sugarcane and for wheat, the cost of seed material was also an important item of cost.

Changing pattern of input use in the cost of cultivation of wheat in India, the most state protected crop, during the input subsidy regime of the 1970s and 1980s and after 1990 i.e. economic reforms were initiated studied by Raghavan, M (2008). This study uses the time series data. The study analysis shows that not all items of costs increased at the same pace. In case of fixed costs seemed to be a gradual deceleration and conversely, operational costs have increased relentlessly. In the second phase, the study revealed that a steep decline in the labour hours applied in cultivation and also stagnant in casual wages. This is due to the agrarian crisis in that period. Hired human labour, hired machine labour, fertilizers, insecticides, irrigation charges and interest on short-term working capital as taken six items together and fitted linear trend for all states at all periods. From this, it is noticed that even if the 
input subsidy regime continued the costs of cultivation of wheat, one of the most state protected crops, could have increased faster than the increase in the general price level. This shows the weakness of that regime. However, when that regime was in fact discontinued, the paid-out costs of crucial items of agricultural inputs increase at a rate that had not been seen earlier.

The economics of groundnut production in the rainfed area (Tamil Nadu) analyzed by Thiruvenkatachari et al. (1991). The study showed that cost A contributed 61.05 percent to the total cost (cost C) in the case of marginal farmers, whereas it was 77.27 percent in the case of big farmers. The net returns over cost C was Rs. 1674, Rs. 2371 and Rs.2313 in the case of marginal, small and big farmers respectively. It was reported that groundnut production was profitable under rainfed.

\section{Hypothesis}

$\mathrm{H}_{01:}$ The variation between the cost and returns of cultivation is widening.

$\mathrm{H}_{02}$ : Costs and returns of cultivation are different according to their farm sizes.

\section{Methodology}

Confining to the mentioned scope of the study the methodology has been studied to carry out the research work in a scientific way so as to cover comprehensive analysis of the problem. The methodology applied is the methods of sampling and way of determining sample size is described in the following along with the methods and techniques used in the data collection.

The theoretical framework of the study combines economic as well as social aspects with the distress in irrigated and rainfed land cultivation. This deals with the relationship between farming and being distress. An attempt is made to study in depth the evolution of distress in the rainfed and irrigated land agricultural practices, regarding the sustainable livelihood practices. Both quantitative and qualitative methods of research were applied in the study through a collection of data by household survey and in-depth interviews, site visits, and field observations. The secondary data is collected from different sources. For an understanding of costs and returns, calculate Cost A, Cost B, and Cost C and Gross, Farm Business, Family Labour, Net, Farm Investment Incomes. Input and paid out cost play a vital role in cultivation. The costs are obtained from all crops per annum in the study area.

\section{Research Design}

Andhra Pradesh is the largest state with diversified regional dimensions where striking differences exist among the regions. One can find the unequal and uneven distribution of rainfall, natural resources, irrigation infrastructure and agro-climatic conditions which are most important characteristics of the agriculture in the study area and these are very critical to appraise the performance of agriculture. For a better and comprehensive understanding of problems prevailing in the agriculture, a multistage random sampling method is employed. As first step, two districts from North Coastal region of Andhra Pradesh is selected through random sampling. In the next stage, one mandal from each district is selected at random. In the final stage, one village from each of the selected mandal is selected at random. Thus 100 samples of two villages were selected for the study.

\section{Collection of Primary Data}

To fulfill the objectives of the study, a modest attempt is made to conduct an intensive study. A sample of fifty households per village was randomly selected from the total households whose main occupation is cultivation from each of the selected village. As a whole, a number of 100 farm households are selected for the intensive study.

\section{Period of Study}

The primary data was collected from June 2015 to April 2016. 


\section{Sample frame work in North Coastal Andhra Region}

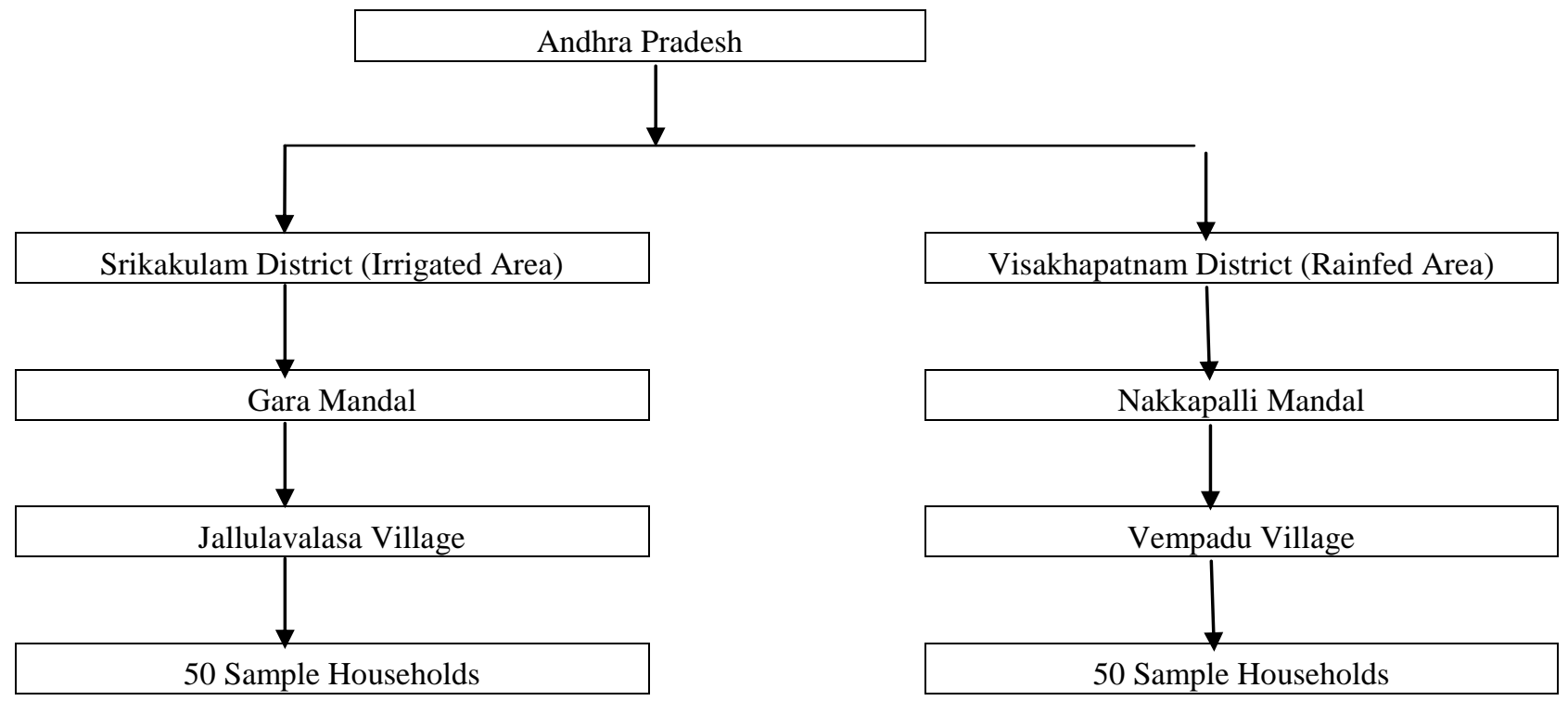

Fig. Flow chart of sample selection

\section{Methods, Results, and Discussions}

Costs and Returns

Costs: The cost involved in cultivation falls into two categories, paid out or actual costs and unpaid or imputed costs. Expenses on hired labour, seed, manure, fertilizer, machinery etc., are examples in the former category while renting on own land, interest on own capital, managerial allowances and family labour are items in the latter category. The cost of cultivation in farming is analyzed in terms of cost concepts used in Farm Management Studies (FMS). In Farm Management Studies there are four important concepts of cost and two important concepts of income that are used. These are:

$\operatorname{Cost} \mathbf{A}_{1}=$ this cost approximates actual expenditure incurred in cash and kind and includes the following cost items: Hired human labour, Owned and hired bullock labour, Seed, Manures and Fertilizers, Implements' charges, Land revenue and other taxes, Irrigation charges, Interest paid on working capital

Cost $\mathbf{A}_{2}=$ Cost $A_{1}$ plus actual rent paid (tenant farmers)

$\operatorname{Cost} \mathbf{B}=\operatorname{Cost} \mathrm{A}_{2}$ plus Rent paid or Evaluated on own land and Interest on fixed capital (excluding land only)

Cost $\mathbf{C}=$ Cost B plus the value of family labour used (both paid out and imputed costs)

Operational Cost $=$ It includes the cost of human labour owned and hired, machine labour owned and hired, seeds, manures and fertilizers, pesticides and water tax.

Overhead Cost = It includes interest on fixed capital, depreciation, rent paid for leased-in land and rental value of owned land.

Paid out costs $=$ These costs refer to expenses incurred on hired or purchased factors. These are the expenses made on seeds, fertilizers, pesticides, hired labour, hired bullock labour, hired machine labour and other hired and purchased inputs. 
IRA-International Journal of Management E゚ Social Sciences

Imputed Costs $=$ These costs include imputed values of owned inputs of farmer such as interest on working and fixed capital, the rental value of owned land, the value of family labour, depreciation, miscellaneous etc.

\begin{tabular}{|c|c|c|c|c|c|}
\hline Inputs & Marginal & Small & Semi-medium & Medium & $\begin{array}{l}\text { All } \\
\text { Farms }\end{array}$ \\
\hline \multirow{2}{*}{ Machine labour } & 1,519 & 2,359 & 3,381 & 3,213 & 2,316 \\
\hline & $(3.61)$ & $(4.20)$ & $(4.41)$ & $(4.39)$ & $(4.11)$ \\
\hline \multirow{2}{*}{ Bullock } & 791 & 1,288 & 1,932 & 1,829 & 1,272 \\
\hline & $(1.88)$ & $(2.29)$ & $(2.52)$ & $(2.50)$ & $(2.26)$ \\
\hline \multirow{2}{*}{ Seed } & 2,291 & 3,731 & 6,175 & 3,838 & 3,754 \\
\hline & $(5.44)$ & $(6.64)$ & $(8.05)$ & $(5.25)$ & $(6.67)$ \\
\hline \multirow{2}{*}{ Manure \&Fertilizer } & 2,567 & 3,794 & 4,590 & 4,824 & 3,569 \\
\hline & $(6.10)$ & $(6.75)$ & $(5.99)$ & $(6.60)$ & $(6.34)$ \\
\hline \multirow{2}{*}{ Pesticides } & 1,894 & 2,760 & 3,914 & 4,300 & 2,764 \\
\hline & $(4.50)$ & $(4.91)$ & $(5.10)$ & $(5.88)$ & $(4.91)$ \\
\hline \multirow{2}{*}{ Hired labour } & 3,896 & 6,166 & 10,250 & 10,050 & 6,403 \\
\hline & $(9.26)$ & $(10.97)$ & $(13.37)$ & $(13.75)$ & $(11.37)$ \\
\hline \multirow{2}{*}{ Owned labour } & 2,792 & 3,729 & 3,418 & 5,500 & 3,394 \\
\hline & $(6.63)$ & $(6.64)$ & $(4.46)$ & $(7.52)$ & $(6.03)$ \\
\hline \multirow{2}{*}{$\begin{array}{l}\text { Rental value of Leased-in } \\
\text { land }\end{array}$} & 571 & 1,366 & 1,836 & 0 & 1,134 \\
\hline & $(1.36)$ & $(2.43)$ & $(2.39)$ & $(0.00)$ & $(2.01)$ \\
\hline \multirow{2}{*}{ Rental value of Owned land } & 15,108 & 16,365 & 18,942 & 23,925 & 16,782 \\
\hline & $(35.90)$ & $(29.12)$ & $(24.71)$ & $(32.73)$ & $(29.81)$ \\
\hline \multirow{2}{*}{ Irrigation Cost } & 2,257 & 3,495 & 6,055 & 2,875 & 3,588 \\
\hline & $(5.36)$ & $(6.22)$ & (7.90) & (3.93) & $(6.37)$ \\
\hline \multirow{2}{*}{ Transport cost } & 543 & 843 & 1,208 & 1,148 & 827 \\
\hline & $(1.29)$ & $(1.50)$ & $(1.58)$ & $(1.57)$ & $(1.47)$ \\
\hline \multirow{2}{*}{ Interest on working Capital } & 3,925 & 3,478 & 6,272 & 1,453 & 4,173 \\
\hline & $(9.33)$ & $(6.19)$ & $(8.18)$ & $(1.99)$ & $(7.41)$ \\
\hline \multirow{2}{*}{ Interest on Fixed capital } & 859 & 1,424 & 2,536 & 5,423 & 1,625 \\
\hline & $(2.04)$ & $(2.53)$ & $(3.31)$ & $(7.42)$ & $(2.89)$ \\
\hline \multirow{2}{*}{ Depreciation } & 1,793 & 2,370 & 2,556 & 2,436 & 2,206 \\
\hline & $(4.26)$ & $(4.22)$ & $(3.33)$ & $(3.33)$ & $(3.92)$ \\
\hline \multirow{2}{*}{ Marketing } & 543 & 843 & 1,208 & 1,148 & 827 \\
\hline & $(1.29)$ & $(1.50)$ & $(1.58)$ & $(1.57)$ & $(1.47)$ \\
\hline \multirow{2}{*}{ Miscellaneous } & 750 & 2,188 & 2,398 & 1,147 & 1,675 \\
\hline & (1.78) & $(3.89)$ & (3.13) & (1.57) & $(2.98)$ \\
\hline \multirow{2}{*}{ Total } & 42,083 & 56,198 & 76,670 & 73,106 & 56,297 \\
\hline & $(\mathbf{1 0 0 . 0 0 )}$ & $(100.00)$ & $(100.00)$ & $(\mathbf{1 0 0 . 0 0 )}$ & $(100.00)$ \\
\hline
\end{tabular}

Source: Field Data.

Note: Parenthesis indicates column wise percentage.

The data presented in Table.1dealt the cost conditions prevailing for marginal farmers, the rental value of own land accounts for a major proportion of the cost of cultivation (35.90 percent) in North Coastal Region. Hired labour accounts for 9.26 percent of total input cost in North Coastal Region. In this Region, Manure \& fertilizers and pesticides account for 6.10 percent of the total cost. Rental value of leased in land accounts for 1.36 percent in the total cost. Interest on working capital accounts for 9.33 percent in the per acre input cost. The cost conditions prevailing for small farmers, the rental value of own land (29.12 percent), hired labour (10.97 percent), seed (5.44 
percent) and manure and fertilizers (6.75 percent) occupies their relative shares in the input cost. In case of semimedium farmers, the rental value of own land accounts for 24.71 percent, hired labour accounts for 13.37 percent, interest on working capital accounts for 8.18 percent and seed accounts for 8.05 percent in total input cost. For medium farm size category rental value of own land (32.73 percent), hired labour (13.75 percent), owned labour (7.72 percent) and fertilizers and pesticides (12.48 percent) have their share in input cost.

In overall, the rental value of own land (29.81 percent) has the largest share in total input cost and followed by hired labour (11.37 percent), fertilizers and pesticides (11.25 percent) and interest on working capital (7.41 percent). From the total cost, marginal farmers account for Rs.42, 083 per acre, whereas it is Rs. 56,198 for small farmers per acre for all crops in the study area. The average cost per acre for all crops accounts for Rs. 56,297 in the study area.

Table.2. Per Acre Cost of Cultivation- Size Wise Per Annum: All Crops

\begin{tabular}{|l|c|c|c|c|}
\hline \multicolumn{3}{|c|}{ (In Rupees) } \\
\hline Farming Category & Cost A1 & Cost A2 & Cost B & Cost C \\
\hline Marginal & 23,627 & 24,183 & 39,291 & 42,083 \\
\hline Small & 34,738 & 36,104 & 52,469 & 56,198 \\
\hline Semi-Medium & 52,474 & 54,310 & 73,252 & 76,670 \\
\hline Medium & 43,681 & 43,681 & 67,606 & 73,106 \\
\hline Total & $\mathbf{3 4 , 9 9 8}$ & $\mathbf{3 6 , 1 2 1}$ & $\mathbf{5 2 , 9 0 3}$ & $\mathbf{5 6 , 2 9 7}$ \\
\hline
\end{tabular}

Source: Field Data

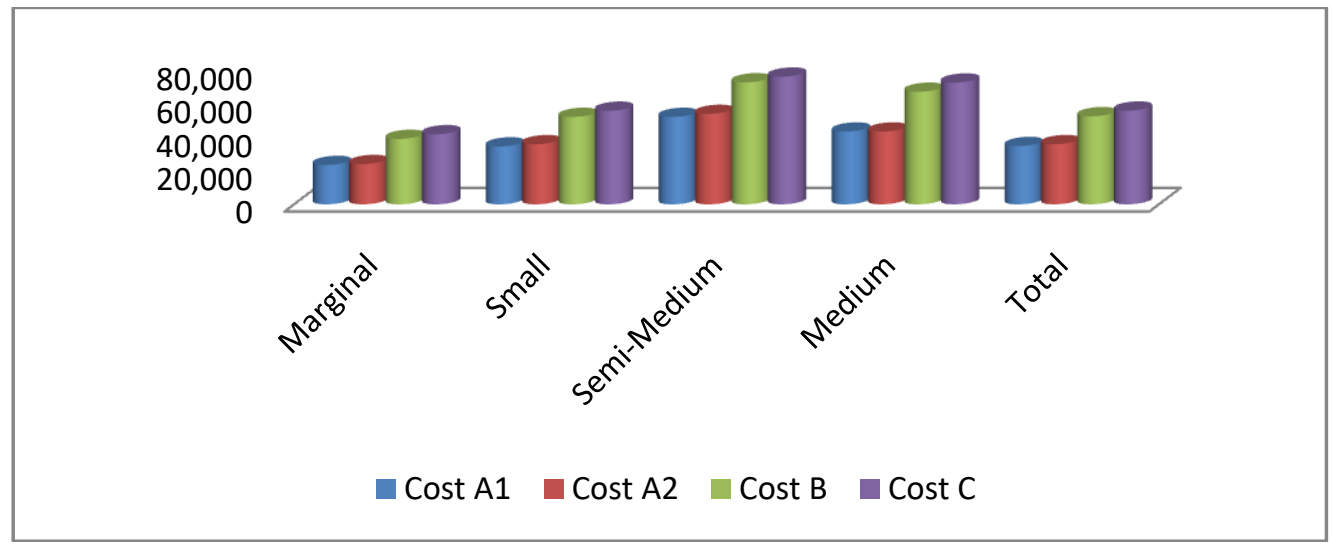

Fig.2. Size-Wise per Acre Cost of Cultivation Per Annum

The Cost of cultivation per acre for all crops by farm size wise is given in Table 2. The cost of production per acre for marginal farmers, Cost $\mathrm{A}_{1}$ accounts for Rs. 44,707, cost $\mathrm{A}_{2}$ accounts for Rs. 57,773, cost B accounts for Rs. 70,110 and cost $C$ accounts for 72,835. The same in the case of small farmers Rs. 51,235, 67,797, 79,207 and 83,431repectively. For semi-medium farmers cost $\mathrm{A}_{1}$ accounts for Rs. 38,115, Cost $\mathrm{A}_{2}$ accounts for Rs. 49,746, Cost B accounts for 71,822 and cost $\mathrm{C}$ accounts for Rs. 74,625.

The operational and overhead costs per acre for all crops size wise presented in table3. For marginal farmers, operational costs account for 42.38 percent and overhead cost accounts for 57.62 percent of total cost. For small farmers the same accounts for 49.03 percent and 50.97 percent for operational and overhead costs respectively. For semi-medium farmers, operational cost accounts for 52.96 percent and overhead cost accounts for 47.04 per in total for all crops. In the case of medium farmers is observed that operational costs account for 52.61 percent and overhead costs account for 47.39 percent in total for all crops in the study area. 
Table.3. Per Acre Operational Cost and Overhead Costs - Size Wise Per Annum: All Crops.

\begin{tabular}{|l|c|c|c|}
\hline & & & (In Rupees) \\
\hline \multirow{2}{*}{ Farming Category } & Operational Cost & Overhead Cost & Total \\
\hline \multirow{2}{*}{ Small } & 18,764 & 23,319 & 42,083 \\
\cline { 2 - 4 } & $(42.38)$ & $(57.62)$ & $(100.00)$ \\
\hline \multirow{2}{*}{ Semi-Medium } & 26,141 & 30,057 & 56,198 \\
\hline \multirow{2}{*}{ Medium } & $(49.03)$ & $(50.97)$ & $(100.00)$ \\
\cline { 2 - 4 } & 42,219 & 34,451 & $(100.070$ \\
\hline \multirow{2}{*}{ Total } & $(52.96)$ & $(47.04)$ & 73,106 \\
\cline { 2 - 4 } & 39,834 & 33,272 & $(100.00)$ \\
\cline { 2 - 4 } & $(52.61)$ & $(47.39)$ & 56,297 \\
\cline { 2 - 4 } & 28,665 & 27,632 & $(100.00)$ \\
\hline
\end{tabular}

Source: Field Data

Note: Parenthesis indicates row-wise percentages.

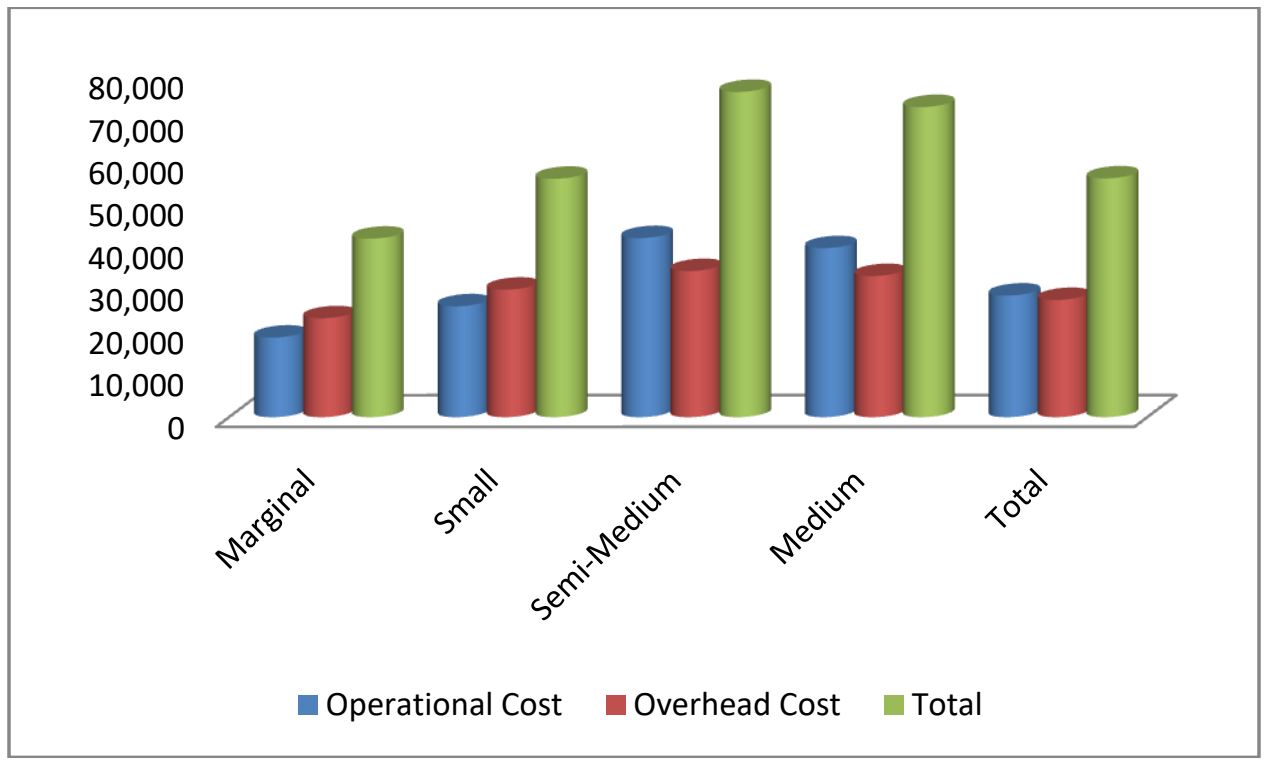

Fig.3. Size-Wise per Acre Operational and Overhead Costs Per Annum.

Overall overhead costs are occupied larger portion in total than operational costs in the study area. It is observed that operational costs are increases with increase the farm size.

Paid out and imputed costs per acre size wise presented in table.3. The paid out and imputed costs per acre for all crops account for 43.81 percent and 56.19 percent for marginal farmers. In the case of the same for small farmers are 53.04 percent and 46.96 percent respectively in the study area. Foe semi-medium farmers paid out and imputed costs are 59.51 percent and 40.49 percent respectively. 
Table.3. Per Acre Paid Out and Imputed Costs- Size Wise Per Annum: All Crops

(In Rupees)

\begin{tabular}{|l|c|c|c|}
\hline Farming Category & Paid out costs & Imputed costs & Total \\
\hline \multirow{2}{*}{ Marginal } & 18,435 & 23,648 & 42,083 \\
\cline { 2 - 4 } & $(43.81)$ & $(56.19)$ & $(100.00)$ \\
\hline \multirow{2}{*}{ Small } & 29,805 & 26,393 & 56,198 \\
\cline { 2 - 4 } & $(53.04)$ & $(46.96)$ & $(100.00)$ \\
\hline \multirow{2}{*}{ Semi-Medium } & 45,623 & 31,047 & 76,670 \\
\cline { 2 - 4 } & $(59.51)$ & $(40.49)$ & $(100.00)$ \\
\hline \multirow{2}{*}{ Medium } & 40,272 & 32,834 & 73,106 \\
\hline \multirow{2}{*}{ Total } & $(55.09)$ & $(44.91)$ & $(100.00)$ \\
\cline { 2 - 4 } & 30,294 & 26,003 & 56,297 \\
\cline { 2 - 4 } & $(53.81)$ & $(46.19)$ & $(100.00)$ \\
\hline
\end{tabular}

Source: Field Data

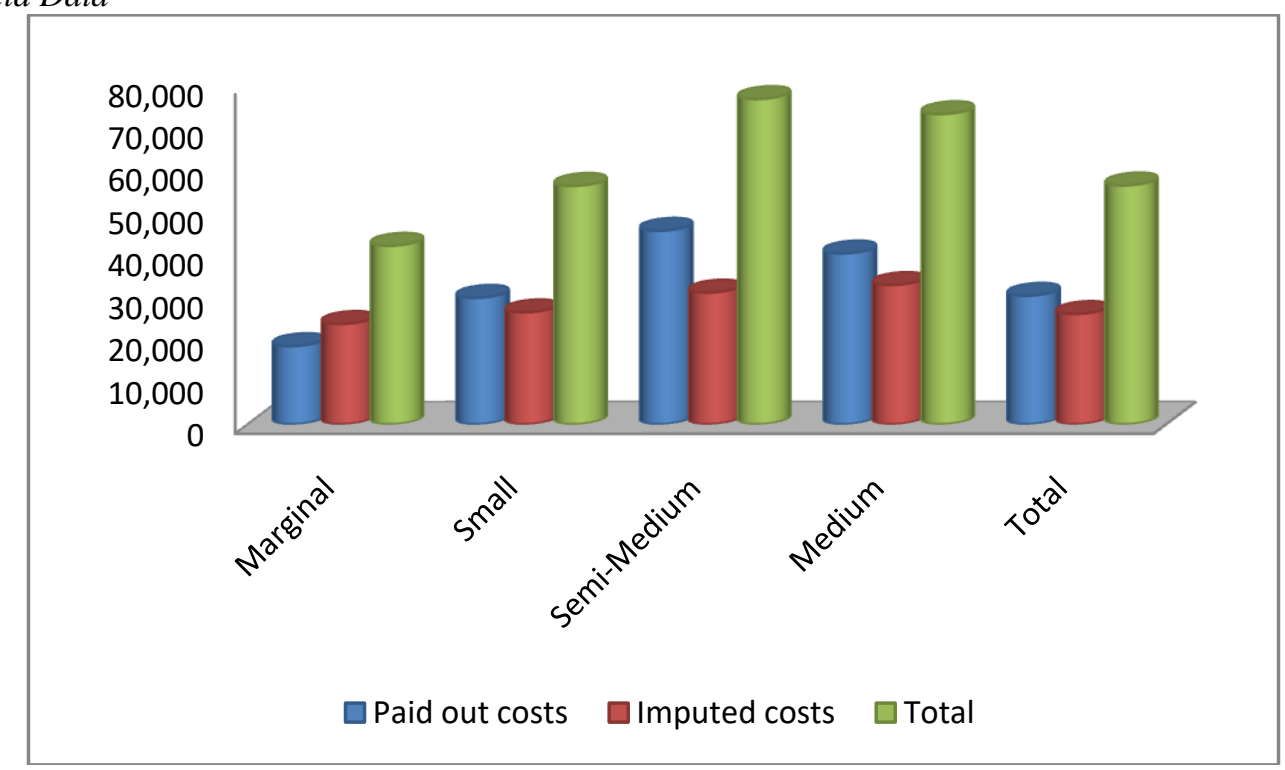

Fig.4. Size-Wise per Acre Paid out and Imputed Costs Per Annum.

The paid out and imputed costs for medium size farmer's accounts for 55.09 percent and 44.91 percent respectively in total cost. Paid out costs are increased with an increase in farm size except for medium size farmers. This is may be small farmers are become medium farmers due to the tenancy of land from big farmers. Whereas in the case of imputed costs the opposite trend observed.

\section{Returns (Income Concepts)}

Gross Income $=$ Gross income is the value of total output.

Farm Business Income = Farm business income represents returns to the farmer from land, family labour, interest on fixed capital and management $=$ Gross Income- Cost $\mathrm{A}_{2}$

Family Labour Income = Family labour income is returned to family labour and management farming. Gross Income- Cost B.

Net Income $=$ It refers to the income from the farm business. Gross Income - Cost C. 
Farm Investment Income $=$ It refers to the income from investment on farming. It includes rental value of owned land, interest on fixed capital and reward for management.

Gross income, Farm business income, family labour income and farm investment income for all crops size wise presented in the Table. 5. Gross agricultural income per acre increases with increase the farm size. Net agriculture income is negative except in medium size farmers.

Table.5. Per Acre Gross, Farm Business, Family Labour, Net, Farm Investment Income Size Wise Per Annum- All Crops (In Rupees)

\begin{tabular}{|c|c|c|c|c|c|}
\hline $\begin{array}{c}\text { Farming } \\
\text { Category }\end{array}$ & Gross Income & Net Income & $\begin{array}{c}\text { Farm Business } \\
\text { Income }\end{array}$ & $\begin{array}{c}\text { Family Labour } \\
\text { Income }\end{array}$ & $\begin{array}{c}\text { Farm } \\
\text { Investment } \\
\text { Income }\end{array}$ \\
\hline Marginal & 34,702 & $-7,381$ & 10,519 & $-2,349$ & 18,208 \\
\hline Small & 50,595 & $-5,604$ & 14,491 & 916 & 20,580 \\
\hline Semi-Medium & 58,719 & $-17,952$ & 4,408 & $-11,448$ & 24,563 \\
\hline Medium & $1,24,205$ & 51,099 & 80,524 & 62,810 & 35,558 \\
\hline Total & $\mathbf{4 9 , 6 0 5}$ & $\mathbf{- 6 , 6 9 2}$ & $\mathbf{1 3 , 4 8 4}$ & $\mathbf{- 5 0 4}$ & $\mathbf{2 1 , 2 0 2}$ \\
\hline
\end{tabular}

Source: Field Data.

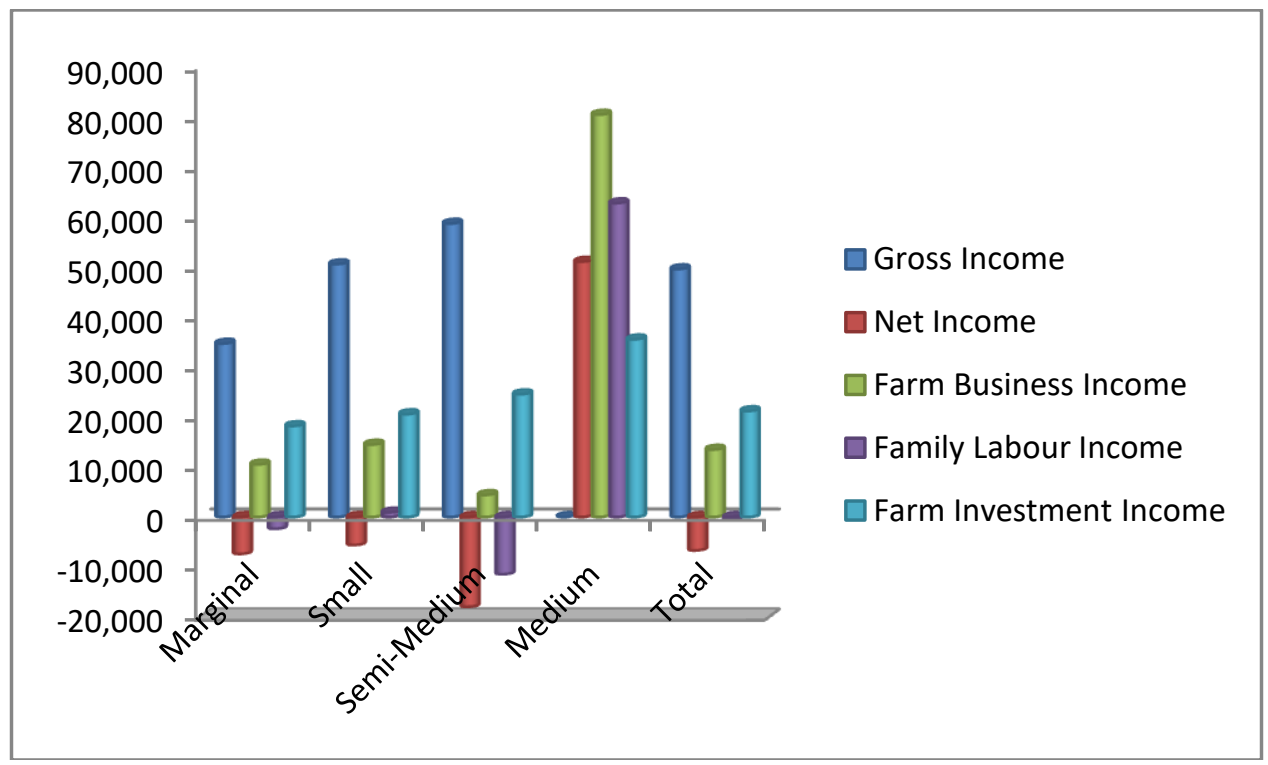

Fig.5. Per Acre Gross, Farm Business, Family Labour, Net, Farm Investment Income Size Wise Per Annum-All Crops

Farm business investment income in marginal farmer's accounts for Rs. 18,208, small farmers account for Rs. 20,580, semi-medium farmers accounts for 24,563 and medium farmers' accounts for Rs.35, 558.

\section{Summary and Conclusion}

The mechanism of reforms was not given enough government funding and financial assistance to the agriculture sector. This impacted the conditions of cultivation, particularly in rural living conditions. The impact of free trade brought unstable prices, difficulties in exports and imports of agricultural products and which is affected farmer's 
welfare, livelihood, and other employment alternatives. The most adverse effect that has become a curse to farmers is the multiple of low price and instability in the output of cash crops.

The most adverse effect that has become a curse to farmers is the multiple of low price and instability in the output of cash crops. Agriculture in Andhra Pradesh mostly depends on rainfall. Monsoon and seasonal conditions play a vital role in Andhra Pradesh agriculture. The proportion of area under agriculture is 37.30 percent (Including fish ponds). The gross irrigated area (35.81 lakh hectare) is 48.29 percent of gross area sown (74.18 lakh hectare.) in the state. The ratio of gross irrigated area to net irrigated area is 1.32 in 2016-17, whereas it was 1.29 in 2015-16. (Agricultural Statistics at a Glance 2016-17).

In overall, the rental value of own land (29.81 percent) has the largest share in total input cost and followed by hired labour (11.37 percent), fertilizers and pesticides (11.25 percent) and interest on working capital (7.41 percent). From the total cost, marginal farmers account for Rs.42, 083 per acre, whereas it is Rs. 56,198 for small farmers per acre for all crops in the study area. The average cost per acre for all crops accounts for Rs. 56,297 in the study area.

The operational and overhead costs per acre for all crops size wise presented in table3. For marginal farmers, operational costs account for 42.38 percent and overhead cost accounts for 57.62 percent of total cost. For small farmers the same accounts for 49.03 percent and 50.97 percent for operational and overhead costs respectively. For semi-medium farmers, operational cost accounts for 52.96 percent and overhead cost accounts for 47.04 per in total for all crops. In the case of medium farmers is observed that operational costs account for 52.61 percent and overhead costs account for 47.39 percent in total for all crops in the study area. Overall overhead costs are occupied larger portion in total than operational costs in the study area. It is observed that operational costs are increases with increase the farm size.

The paid out and imputed costs per acre for all crops account for 43.81 percent and 56.19 percent for marginal farmers. In the case of the same for small farmers are 53.04 percent and 46.96 percent respectively in the study area. For semi-medium farmers paid out and imputed costs are 59.51percent and 40.49 percent respectively. The paid out and imputed costs for medium size farmer's accounts for 55.09 percent and 44.91 percent respectively in total cost. Paid out costs are increased with an increase in farm size except for medium size farmers. This is may be small farmers are become medium farmers due to the tenancy of land from big farmers. Whereas in the case of imputed costs the opposite trend observed. Gross agricultural income per acre increases with increase the farm size. Net agriculture income is negative except in medium size farmers. Farm business investment income in marginal farmers accounts for Rs. 18,208, small farmers account for Rs. 20,580, semi-medium farmers accounts for 24,563 and medium farmers' accounts for Rs.35, 558. From the study, it is observed that all farm sizes are in a distress situation.

Suggestions for Policymakers: 1. Strictly implement the National Commission on farmer's recommendations of increasing MSP should be at least 50 percent more than the weighted average cost of production. 2. Promote Zero Budget Natural Farming (ZBNF) across the country. 3. Introduce availability of the leased technology (i.e. crop sowing and cutting machines etc.) to marginal and small farmers. 4. Reduce the inequalities between villages and towns.

\section{Acknowledgments}

The author thanks to many government officials at the district, mandal and village level without whose help the research would not have been possible

\section{References}

[1]. Raghavan, M. (2008). Changing pattern of input use and cost of cultivation. Economic and Political Weekly, 123129.

[2]. Kathirvel, N. (2013). Cost and Returns of Banana Cultivation in Tamil Nadu with Special Reference to Karur District. Journal of Contemporary Research in Management, 2(1).

[3]. Patnaik, P. (2003). Agricultural Production and Prices under Globalisation. The Retreat to Unfreedom.

[4]. Bastine, L. (1988). C. and Radhakrishnan. V., "Economics of Banana Cultivation in Irinjakkuda Block and Trissur District of Kerala". Indian Journal Agricultural Economics, 43(3), 514. 
[5]. Narayanamoorthy, A. (2013). Profitability in crops cultivation in India: Some evidence from the cost of cultivation survey data. Indian Journal of Agricultural Economics, 68(1), 104-121.

[6]. Deshpande. R.S. and N. Prabhu (2005), "Farmers' Distress: Proof beyond Question", Economic and Political Weekly, Vol. 40, Nos. 44-45, pp. 4663-65.

[7]. Deshpande, R.S. and S. Arora (Ed.) (2010), Agrarian Crisis and Farmer Suicides, Sage Publications, New Delhi.

[8]. Dev, Mahendra, and N.C. Rao (2010), "Agricultural Price Policy, Farm Profitability and Food Security”, Economic and Political Weekly, Vol. 45, Nos. 26 \& 27, June, pp. 174-182.

[9]. Rawal, V. (2013). Cost of Cultivation and Farm Business Incomes in India.

[10]. Surjit, V. (2008), "Evolution of the Study of Cost of Cultivation." paper presented at "Studying Village Economies in India: A Colloquium On Methodology,"

[11]. Ramachandran, V. K., Rawal, Vikas and Swaminathan, Madhura (2010), Socio-Economic Surveys of Three Villages in Andhra Pradesh: A Study of Agrarian Relations, Tulika Books, New Delhi, 2010.

[12]. Rawal, Vikas (2009), "Economic Policies, Tenancy Relations, and Household Incomes: Insights from Three Selected Villages in India", mimeo.

[13]. Thiruvenkatachari, K., Vishwanathan, B. N., \& Seetharaman, K. S. (1991). An economic analysis of groundnut production in the rainfed area - A Case study on Tamil Nadu. Agricultural Situation in India, 46, 431. 